\title{
US fails to quantify threat of West Nile virus
}

Hannah Hoag, Washington

Public-health authorities in North America are gearing up for the return and probable spread of West Nile virus, which last year claimed the lives of more than 200 people.

But despite a national effort involving several federal agencies, including a $\$ 40$ million investment in research and surveillance by the Centers for Disease Control and Prevention (CDC) in Atlanta, Georgia, officials still have no reliable estimate of the likely scale of this year's outbreak.

West Nile virus is carried by birds and is mainly spread to humans by mosquitoes. It is a member of the flavivirus family, which includes yellow fever and St Louis encephalitis, but in humans it is not usually life-threatening, although in about $1 \%$ of cases it causes severe meningitis and encephalitis.

Since it was detected in New York state in 1999, the virus has surged westwards. Last year it infected at least 4,000 people in the United States, killing 284, and public-health officials are predicting that the virus will spread to cover the whole country this year.

But virologists also expect both humans and animal host populations in the United States to begin developing immunity to the virus, as has happened in other parts of the world where the virus is already endemic. However, there is so far no reliable estimate of how long this immunity will take to build up, leaving researchers unsure of the likely death toll for this year.

"We should be prepared for an outbreak just as large, if not larger than last year's," says Lyle Petersen, of the CDC's division for vector-borne diseases. "There is nothing to prevent it from happening again."

US researchers have identified 36 species of mosquito that can carry and transmit the virus to humans, although three species of Culex mosquito seem to be responsible for most US cases.

Last year, 21 people were infected through blood transfusions, and four became infected after receiving organ transplants from infected donors. Two companies are developing screening tests in an effort to prevent further human-to-human transmission of the virus. The tests are expected to be ready by 1 July.

But experts are criticizing the US response to the virus, describing current efforts as patchy. Because of funding cuts, some state health departments have dispensed with bird surveillance programmes, which track and identify the incidence of the virus in birds, on the premise that the virus has already become endemic.

In California, where the virus has yet to arrive and where the relatively high number of outdoor workers, such as farm labourers,

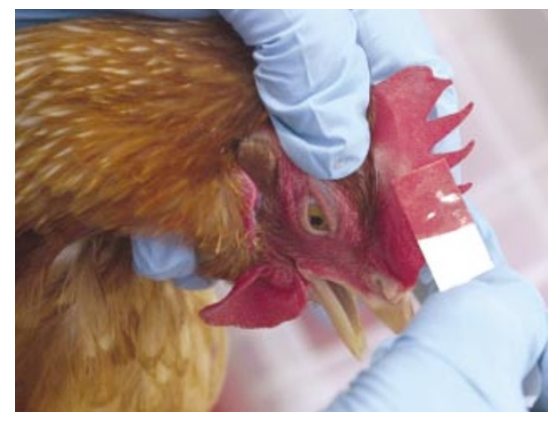

Blood is taken from a Californian chicken as part of an early warning screen for West Nile virus.

could heighten health risks, officials are preparing for the worst. "We fully expect that West Nile virus will be introduced and become established this summer," says Vicki Kramer, chief of the vector-borne disease section of the state's health department. California has established a network of 200 chicken flocks which will be monitored by health officials for the arrival of the virus.

University researchers and biotechnology companies, meanwhile, are trying to develop a vaccine. Drug firm Acambis in Cambridge, Massachusetts, for example, this summer plans to begin human safety trials of a live vaccine, based on an established vaccine against yellow fever. A DNA vaccine - derived from the virus's RNA and one derived from its protein coat are also being developed.

Other researchers are looking at how to improve control of the mosquitoes. Researchers at the US Agricultural Research Service in Gainesville, Florida, have identified a baculovirus that selectively infects and kills the Culex mosquito. But the team has yet to find a commercial partner to develop the idea into an insecticide that could be approved and used.

\section{Los Alamos contract open to bids}

\section{Geoff Brumfiel, Washington}

Researchers at Los Alamos National Laboratory in New Mexico are facing an uncertain future after the US Department of Energy (DOE) announced that it will accept bids from new contractors to run the lab. For the whole of its 60-year history, the nuclear-weapons laboratory has been managed by the University of California.

Scientists credit the university with fostering an atmosphere of academic rigour and intellectual openness that they fear could disappear under management by a corporation or other institution. "There's great concern that the intellectual capability of this lab could just dissolve," says William Priedhorsky, chief scientist in Los Alamos' nonproliferation division.

The DOE says that its decision, announced on $30 \mathrm{April}$, is a response to recent fraud cases involving lab employees, and to inventory audits that highlighted missing or misplaced equipment (see Nature 421, 99-100; 2003). "The problems at the lab represent a systemic management failure," Linton Brooks, head of the National Nuclear Security Administration — the DOE agency that oversees the lab - told a congressional committee. The department will seek competitive bids to run the lab from September 2005, when the university's existing contract expires.

But some observers charge that the decision is driven in part by the Bush administration's desire to make trouble for Gray Davis, the Democrat governor of California. Organizations close to the administration, including the University of Texas and the engineering firm Bechtel, are thought to be top candidates for running the lab. "This is ultimately a political decision," says one scientist working at the laboratory. "This administration doesn't have much love for the state of California."

Management issues at Los Alamos have also raised the ire of Congress, which has been growing impatient with the lab since Wen Ho Lee, a mechanical engineer there, was accused of passing weapons secrets to a foreign power in 1999. And now even the lab's most ardent congressional supporters, such as Senator Pete Domenici (Republican, New Mexico), are conceding that other institutions should be allowed to compete for the management contract.

Richard Atkinson, the University of California's president, says that he is unsure whether the university will compete for the contract. But he adds that if it does, it will be without fanfare or the millions of dollars usually expended to win such a role.

Los Alamos officials say that they have already begun to feel the effects of the DOE's decision. Retirement applications have almost doubled compared with the same time last year, and recruitment is also being adversely affected. "It's foolish to throw away a contractor that is one of the best publicly run universities in the world," says Albert Migliori, a physicist and 30-year veteran of the laboratory.

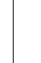

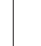

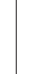

